\title{
In evidence: Linguistic transformations of events in police interview reports
}

\section{Gunilla Byrman \& Ylva Byrman}

The aim of this article is to examine how police investigators reproduce interviewees' utterances in narratives, in direct and indirect reported speech, and by enclosing words in reports in quotation marks. Drawing on a larger study of professional writing, the pertinent research question for the current investigation is how writing techniques in police interview reports convey evidential value in the form of reported utterances. A corpus of police reports on domestic violence is explored from the theoretical perspectives of critical discourse analysis, polyvocality and reportative evidentiality. A new analytical framework for polyvocal texts is developed in terms of utterance, source and framer. The results show that it is difficult to determine whether or not words placed within quotation marks are meant to present verbatim quotes. Another finding is that police investigators are not consistent in documenting utterances from different sources, or in showing whether utterances are embedded in other utterances. This may obscure the structure of the original events and the source of crucial utterances, resulting in unclear evidential status for police reports.

Keywords: direct and indirect reported speech, evidential value, framer, narration, police interview reports, polyvocality, quotes, quotation marks, source, utterance

Gunilla Byrman, Institutionen för svenska språket, Linnéuniversitetet, 35195 Växjö, Sweden. gunilla.byrman@lnu.se

Ylva Byrman, Institutionen för svenska spräket, Göteborgs universitet, Box 200, 40530 Göteborg, Sweden.

ylva.byrman@svenska.gu.se

\section{INTRODUCTION}

This article addresses the retelling techniques used in investigative interview reports written by the Swedish police, and the consequences these techniques have for their evidential value, specifically reportative evidentiality (Mushin 2001, Aikhenvald 2007), i.e. who is the perceived source of information for a given statement in the texts (Yang 2014). The aim is to examine how the police, through different writing techniques, reproduce interviewees' utterances in their written reports through different types of reported speech such as indirect speech, direct speech and narration (Fairclough 1995:55-57; Toolan 2001; Galatolo 2007; Leech \& Short 2007). We examine texts from domestic violence cases, where plaintiffs, suspects and witnesses 
are interviewed, and a key assumption is that no text has an entirely fixed and stable meaning, but rather a meaning potential that is more or less open to an intended reader's possible interpretations (Linell 2009, Heffer, Rock \& Conley 2013). An institutional text such as a police report built on interviews has multiple recipients and is written to serve different and specific purposes, in this case to be of use in the forthcoming judicial process. Komter (2006, 2013), Park \& Bucholtz (2009:488489), Heffer (2005, 2010), Seawright (2012:5), Haworth (2013), Heydon (2013) and Johnson (2013) have studied different aspects of documentation in the legal process. The interview situation is complex and interviewing officers must manage and divide their attention between several activities in the course of the interview. As Rock (2001:44) puts it, 'as a speech event, [the police interview] consists of multiple tasks - telling, listening, writing, formulating, analysing - and has multiple goals - the extraction, communication and the use of emotional and factual information'.

It is important to raise awareness among investigators within the police about how different future readers may interpret an interview report, for example, to what extent readers will be able to judge with certainty from the text whether a specific piece of information was given spontaneously by the interviewee, elicited by a police question or did not belong to the interview at all, but was added later by the police (Holt \& Johnson 2010).

The research questions for this study are:

- What techniques do the police use to retell the interviewees' story in the written interview reports?

- How do these techniques convey evidential value in the interview reports?

These questions will be explored through an in-depth analysis of two text extracts from a corpus of interviews, as well as illuminating examples from other texts in the corpus. We will examine who seems accountable for the utterances in the text. We have designed a tentative method for examining the way utterances are handled in the texts and aim to demonstrate how polyvocality can be analysed in texts in terms of utterance, source and framer (see definitions below, in Section 3, and analysis in Section 5; see Byrman \& Byrman 2012). What is at stake here is the reportative evidentiality of the utterances in the text, i.e. who is appointed as the source of information (see also Yang 2014).

The written interview reports deal with the retelling of at least two different events or scenes: the event of the interview and the event of the alleged crime itself. In the oral interview, the interviewee recounts the events of the suspected criminal incident to the police. In the written interview report, the police recounts the event of the interview: what the interviewee has recounted. Thus, the written report becomes a retelling of a retelling of the events of the criminal incident; the interviewee's account of the criminal incident is embedded in the police account of the interview. Figure 1 illustrates the two situations: an interview and a crime scene. 


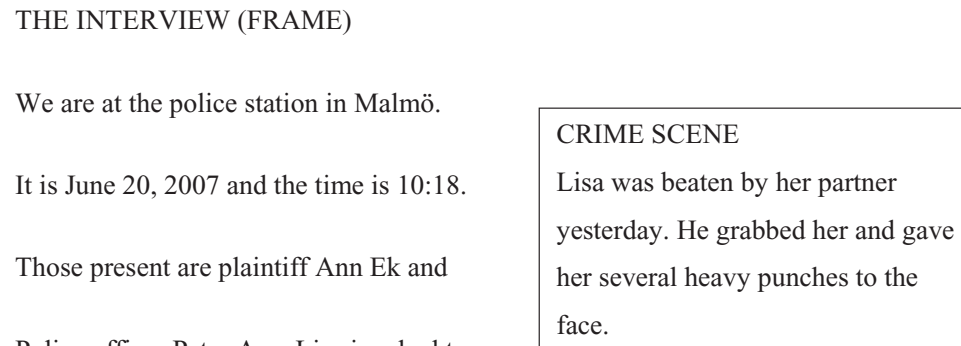

Figure 1. The situation during the interview: An interview and a crime scene.

Since our cases concern domestic violence, at least two parties will be interviewed, the plaintiff and the suspect, so the police need to retell two often competing and contradictory accounts of the events of the alleged crime. ${ }^{1}$ The box model in Figure 1 is simple, with only two main voices heard in each report: the interviewee's and the police's. But as we will show, yet other voices will also sometimes be embedded in the report, for example when an interview is carried out with an interpreter or when the interviewee quotes what other people at the crime scene said, further complicating possible interpretations. All these are examples of how transformations from one enunciator (Chafe 1986:262) to the next may change the meaning of the words as originally uttered. What happens in our material is that spoken language is translated into a multi-voiced text focused on what is essential for the legal process. In the legal context, however, it is crucial to ensure that utterances are attributed to the person who provided them. We raise the very real possibility that the linguistic choices analysed in this study are so subtle that report-writing investigators are hardly aware of the effect they may have on the possible interpretations of the utterances' evidential value. For example in the sentence 'Amma states that Ali uses her and uses Azra's passport to "pressure" her', it is not obvious how the word in quotation marks should be interpreted by the reader. It could be a way to frame Azra's verbatim word, but it could also be a way for the investigator to show that the word has a stylistic value that is not considered appropriate in an investigative text, did not originate in the interview context, or show, for instance, ironic distance to the word. This example shows that there are at least three different possible interpretations, which demonstrates the problem of evidential value - and that the devil is in the detail.

\section{POLICE INTERVIEW REPORTS IN SWEDEN: REGULATIONS AND REALITY}

When a crime is committed and reported to the police in Sweden, an investigation report is normally opened and suspects, plaintiffs and witnesses are interviewed by 
the police. These interviews can be video- or audio-taped, but are often not recorded at all (Byrman 2017:146-148). The police officer (or investigator) who carries out the interview sums it up in a written report not unlike the English genre of witness statement $^{2}$ (Rock 2001, 2010). In Sweden, it is legally required that the report be read by (or read out aloud to) interviewees to allow them to review if their words have been rendered correctly before giving their approval. These interview reports then become part of the larger investigative report and therein make important material for public prosecutors, because they form a vital basis for the decision whether to drop the case or take it to court. During trial, suspects, plaintiffs and witnesses will normally be re-asked questions that they have already replied to during the police investigation, since the Swedish justice system is built on the principle of orality: everything that is going to be assessed in the judicial process must be stated orally during the trial.

The form of the interview report is not explicitly regulated in any detail, though the Investigation Report Decree (Swedish: Förundersökningskungörelsen) from 1947 formulates some guiding principles for how the written documentation should render spoken statements (the original text here is followed by our own English translation):

\section{$\$ 22$}

Protokoll skall avfattas så, att det ger en trogen bild av vad som förekommit vid förundersökningen av betydelse för målet.

Utsaga skall, $i$ de delar den anses böra intagas i protokollet, återgivas $i$ så nära överensstämmelse som möjligt med det talade ordet. Ordagrann återgivning behöver dock ej ske annat än då det ligger vikt på att de exakta ordalagen inflyta i protokollet. Utsaga som ordagrant antecknats $i$ protokollet skall sättas inom citationstecken.

(Förundersökningskungörelsen 1947)

\section{$\S 22$}

'A report shall be worded so as to give a true picture of anything of importance for the case that emerged from the investigation.

'Utterances, in those parts where it is considered that they should be included in the report, shall be reproduced as closely as possible to the spoken word. They need not, however, be rendered verbatim except when it is important that the exact wording should be recorded in the report. An utterance which is recorded verbatim in the report shall be placed in quotation marks.'

Note that the decree specifically mentions that there is no need for quotations unless a verbatim quotation is considered crucial. This is normally only the case when the utterance is considered to refer to a constituent element of the crime, such as threats, verbal abuse and abuse of judicial procedure. The National Police Board in Sweden has published recommenations (Riktlinjer för skrivande inom polisen [Guidelines for writing in the police] 2006), giving more detailed advice on how police's written 
language may be improved. They explicitly state that the police should reserve (double) quotation marks for verbatim quotations and that scare quotes around slang words or colloquial expressions, as a means of distancing oneself from the language of the interviewee, should be avoided.

However, all research on Swedish police writing shows that scare quotes around colloquial expressions are a common feature (Jönsson 1988, Gumbel 2000, Pappinen 2010). Most interesting are the findings of Jönsson (1988), who compared audio recordings of interviews with the written reports and showed that quotation marks were sometimes used around expressions that were never uttered by the suspects at all, but were in fact the policeman's own words. Jönsson shows that on average only $36 \%$ of the primary sources of the statements in the reports are the interviewees' own account of the events. The rest consists of answers to police questions or utterances added by the police (Jönsson 1988:57).

An explanation for this distribution of sources in interview reports is that the investigator must produce a reasonably coherent and focused text, and not a transcript (for which police are not trained anyway). Furthermore, the investigator becomes a co-constructor of the story-line by adding relevant information about the crime and narrative elements that will make the text coherent. In this study, we will illustrate the reporting practice in the Swedish legal system.

The above-mentioned research shows that what is stipulated in formal regulations often differs from actual practice, and one may question to what extent the writing guidelines are adhered to or even read at all by investigators. In fact, police in general are not very eager to discuss issues of report writing or how linguistic and textual choices might affect the interpretation of their reports and as a consequence also the prosecution process (see Seawright 2012, Byrman 2014). Report writing is usually not a particularly valued skill among police officers themselves, even though it takes up much of their working time, since every major event has to be documented. In other words, the police are what Spinuzzi \& Jakobs (2013) label INTEGRATED WRITERS, i.e. professionals who use writing extensively but do not see themselves as professional writers. Rather, writing is perceived as a less important and unloved part of their work and, according to Jakobs (2008), integrated writers often have deficient problem-solving strategies when they write, e.g. weak revising strategies and weak addressee-orientation strategies (see also Heydon 2013).

Reporting officers must use the means available in writing to indicate the source of an utterance, which is challenging when faced with the simultaneous tasks of transforming speech to writing and adhering to standards imposed by the legal context (Byrman 2014:260). The investigators have to translate the event into a legal framework. In doing so, they have to indicate who did what to whom and who said what to whom. All this is based on spoken retellings of past events with all the obvious uncertainties following from that. The fact that there are no strict rules on how interviewees' spoken words should be reproduced in written texts (apart 
from direct quotes, see above) potentially poses serious consequences for the judicial outcome of criminal cases, not least for the persons involved.

\section{THEORY: POLYVOCALITY, MEANING POTENTIALS AND EVIDENTIALITY}

In this section we present some assumptions and theoretical concepts, such as polyvocality, meaning potentials and evidential value, and discuss how these can be applied in our study. We also present the linguistic tools available to investigators when reporting other people's speech that we focus on here, namely narration, direct and indirect reported speech, utterance, source and framer. On the whole, the theoretical framework in this study concerns textual travel in the legal system and what may happen to texts in the process of being entextualised, decontextualised and recontextualised (Bauman \& Briggs 1990; Heffer 2005; Andrus 2015), and we specifically make use of Dialogical Language Theory to frame and inform our discussions about linguistic choices in the interview reports.

Dialogical Language Theory is based on Vygotsky and the Bakhtin School (see e.g. Vygotsky 1978; Bakhtin 1981, 1986; Vološinov 1983), and in this theory it is assumed that every utterance and every text interacts with a social and historical context, and therefore cannot be regarded as an isolated phenomenon. During text production, the writer is more or less aware of the reader, which affects the linguistic choices. Reading a text is also viewed as an (indirect) interaction with the writer. Both participants - writer and reader - interact with previous experiences or opinions: 'The true essence of language is the social event of speech interaction, manifested by one or several utterances' (Vološinov 1983:115). But there are other forces related to texts and genres, and these derive from the social, cultural and historical context; an intertextual chain is created (see Mateosian 2000:879). At one end of an intertextual axis the genre convention has a stabilising effect on the text by adapting the text to the use of the genre. Genre conventions and established patterns in the language enable understanding. The other end of the axis allows an utterance to be unique and innovative, thus challenging the genre's convention (see Ajagán-Lester, Ledin \& Rahm 2003). This dual dialogue takes place as a negotiation between the writer and the reader and the culture's expectations of language and text.

A dialogical perspective on meaning and understanding proceeds from the premise that tensions and struggles are always present. Human action and communication are always oriented towards agreement, but at the same time, meanings and understandings can never be made totally explicit, since one person's understanding, views and experience of the world will never be entirely identical to another's (Linell 2009). A concept in dialogism is that of POLYVOCALITY, referring to the fact that any text will embed and echo the voices of others to a greater or lesser extent. We draw upon Linell's (2009:246f.) theory of dialogism in analysing 
our data. Often polyvocal analysis is focused on revealing the more subtle cases of implicit embedding and interweaving of texts or voices, compare Kristeva's term INTERTEXTUALITY (Chouliaraki \& Fairclough 1999:118-119).

Such concepts would undoubtedly also be fruitful for analysing the mixing of the everyday lifeworld discourse of the interviewee and the institutional discourse of the legal system in investigative interview reports. In this study, however, we will touch especially on polyvocality in its most concrete and manifest sense, namely, how voices and perspectives of the speakers in the interview are embedded in the written interview report.

As in all genres, we find a mix of writing techniques in police interview reports. The whole report is often a NARRATION, which could be defined as the semantic representation of a series of events in the form of a story, i.e. a narrative. Toolan (2001:8) summarises a narrative as 'sequences and interrelated events; foregrounded individuals; crisis to resolution progression'.

In narratives written by the police, we find mostly DIRECT and INDIRECT REPORTED SPEECH, for short, DIRECT and INDIRECT SPEECH. For example, one can answer the question 'What did he say?' in two ways: by repeating the words spoken (direct speech) or by reporting the words spoken (indirect speech). Ideally, direct speech repeats, or quotes, the exact words of the person who spoke them. When reproducing direct speech in writing, the convention is to place the quoted words between quotation marks to show that it is a verbatim reproduction with no change of the words. Quotations are often introduced or followed by a framer, such as the Swedish han sa 'he said', allowing for a relative placement of the original speech situation vis-à-vis the current situation of retelling through choice of verbal tense form (e.g. Swedish sa or säger 'said' or 'says').

In indirect speech, both present and past tense can be used to talk about the past. For written police interviews, Swedish regulations instruct investigators to use the past tense to 'describe completed events, [since] it is sometimes obviously illogical when the present tense is used' (Riktlinjer för skrivande inom polisen 2006:10). Accordingly, they must change the tense and other deictic markers of the words spoken, such as pronouns or adverbs of time and place. They can also use reporting verbs like säger 'says', berättar 'tells' and frågar 'asks', as well as pronouns jag 'I' and $v i$ 'we', and the complementiser att 'that' to introduce the quotation. Compare the two techniques below:

\begin{tabular}{|c|c|c|}
\hline $\mathrm{nn}$ & & \\
\hline Ann & & \\
\hline
\end{tabular}

Indirect speech

Ann sa att hon hade sett honom.

'Ann said that she had seen him.' 
In the examples above, we can see that not only the tense of the verb is affected but also the personal pronouns, depending on whether the writer presents the utterance through direct or indirect speech.

In the rest of this article, we distinguish between the SOURCE of an utterance and the FRAMER. A source is the textual representation of the enunciator of the original utterance (here Ann). A framer is the textual representation of the activity of uttering, including the source (here Ann sa 'Ann said' and Ann säger 'Ann says'). Framers construe the rhetorical and contextual setting of reported utterances by selecting specific reporting verbs (see also Ask 2018) and tenses. To sum up, a framer is a marker of reported speech that not only shows that what follows is an embedded utterance, but also explicitly ascribes this embedded utterance to a given source, such as the interviewee.

In addition to direct and indirect reported speech, an alternative way of writing in the written investigative interviews consists of (parts of) narratives. A narrative is a way to sort and organise events, actions and events chronologically in one way or another. The various parts of the narrative can cover an entire course of events, and most narratives also contain descriptive, explanatory or argumentative sequences (in fact, the text would otherwise become unreadable).

The perspective in a narrative is similar to the camera's position in recording a film; a report produced by an investigator retells the interviewee's narrative in a third person perspective. Hence, the police officer is in control of the writing process, which can be a problem in investigative interviews (see Jönsson 1988). It ought to be the interviewee's perspective that is presented in written investigative interviews, but the police officers of necessity become co-constructors of the interviewees' stories in narrative parts of the investigative interviews.

Police interviews are performed, and recorded in written form, to collect evidence about a criminal incident through the elicitation of more or less spontaneously told stories ('free accounts'). In most interviews, the investigator will also ask a series of questions to obtain more precise details, and sometimes to challenge the interviewee's presentation of certain parts of their story.

Another assumption for this study is that verbal language or other semiotic means, such as gestures and gazes, are not codes where every word, symbol or grammatical construction has a fixed and stable meaning. Rather, linguistic resources have MEANING POTENTIALS, which are open to interpretation. The actual meaning is always situated in a unique interaction, and brought into being by the speaker's and listener's intersubjective and contextual understanding of it. Dialogism points out that such understandings can never be made totally complete and explicit (see Linell 2009). At the same time, there must always be some common ground when communication takes place. This tension between alterity (the strangeness of the other's perspective) and intersubjectivity (the common understanding) is present in all human interaction, and successful communication can be thought of as creating 
a sufficient common understanding between participants for their current practical purposes (Garfinkel 1967; Heydon 2013:13-14). The question of what a sufficient understanding actually is and how it can be studied is a difficult but relevant issue in the case of investigative interview reports.

Interviewees in a police report may be plaintiffs, suspected witnesses or expert witnesses. The presence of voices from these interviewees can be described as 'manifest intertextuality' (Fairclough 1992:85), with different voices articulated in the texts. Further, the representation of different voices can introduce different opinions by explicit reference to other sources (Fairclough 1992:85). Thereby, the writers increase the number of voices in their texts; they engage in polyvocality. The result of the writer lifting external voices into the text is that the dialogical space increases with the introduction of different opinions.

In the legal context, the evidential value of reported utterances is very important, since the source, and thereby the credibility, of information in a given utterance can be crucial for the outcome of an investigation or a trial.

It should be pointed out that there is little consensus about the nature of evidentiality, i.e. the linguistic marking of the source of information in a given utterance (Aikhenvald 2007; Boye \& Harder 2009; Yang 2014:581-582). Evidentiality can be considered a notional category concerned with the source-of-knowledge for an utterance (Boye 2010) that is expressed differently across languages, i.e. it is language-specific. In this article, we study reportative evidentiality through verbs, pronouns and adverbs in the reproduction and presentation of interviewees' spoken words in direct and indirect speech and narration as well as the use of quotation marks.

To sum up, the theoretical perspective assumes that the investigative interview reports do not carry fixed meanings, but only meaning potentials open to the reader's interpretation. How the writer constructs, retells and transforms the story of the interviewee and handles the polyvocality of text will play an important role in how the text will be interpreted, and also show how the investigator constructs the evidential value of the reported utterances.

\section{MATERIAL}

The texts for this study come from a written corpus consisting of 80 authentic investigations of domestic violence from five different police stations in Sweden. The corpus comprises 800 texts of various investigative genres that have been digitised and anonymised.

Apart from interview reports that are the focus of this article, the corpus includes police memoranda, initial crime reports, medical reports on documented injuries, expert testimonies of various kinds, and photographs. Ethnographic data have also been collected through field observations, questionnaires and interviews at five police stations in Sweden. 
In our analysis, we want to provide illustrative examples from five different interview reports to show how writers handle the task of reporting speech. The principle for the selection of the texts has been to illustrate the variations and patterns found in our larger material and to show representative examples of the problems and choices involved when different voices are present in the reports.

We use a written corpus because in most cases no voice recordings are available. The written documentation is realistic in that it is the written text and not recordings that all participants deal with when a text travels through the legal system. For the analyses, we use excerpts from investigative interview reports with different parties: plaintiffs, suspects and witnesses. To protect the identity of the people mentioned in the material, we have followed the ethical principles on anonymisation, etc. found and recommended in the humanities and social sciences for research in Sweden (Codex 1990).

\section{METHOD AND RESEARCH DESIGN}

To be able to pin down the linguistic techniques used by the police to retell interviewees' stories, we have operationalised our analytical categories to describe the framing of different voices in the text. Every time writers wish to reproduce someone else's voice, they have to choose a linguistic technique for this reproduction. While such techniques have mainly been studied and categorised by literary scholars (see e.g. Fludernik 1993, Leech \& Short 2007 for an overview), writers producing nonfictive narratives have the same discoursal devices at their disposal. As we have seen, three of the most basic categories for analysing modes of representation are indirect speech, direct speech and narration. In indirect speech, the original utterance is often reproduced as a complement clause. In direct speech, the writer reproduces the speaker's utterance as if verbatim, usually marked by quotation marks. Direct speech and indirect speech are both transparent ways for writers (and speakers) to signal that they are retelling someone else's utterances. But writers often recount the interviewee's words without signalling that they are retelling; that is, they present the facts as if they had observed them themselves, using plain narration.

To demonstrate our analytical approach, we first present a fictive example of an interaction between a caller and the police: Alan calls the police to tell them that his older sister is being abusive. Here is an example of how the police might prompt Alan for more information and how he could respond:

Polisen: Vad hände?

Police: 'What happened?'

Alan: Helen knep mig i armen.

Alan: 'Helen pinched my arm.' 


\begin{tabular}{|c|c|c|}
\hline Utterance & Framer & Source \\
\hline \multicolumn{3}{|l|}{ Indirect speech } \\
\hline $\begin{array}{l}\text { 1. Alan säger att Helen knep honom i } \\
\text { armen } \\
\text { 'Alan says that Helen pinched him in the } \\
\text { arm' }\end{array}$ & & Polis/police \\
\hline $\begin{array}{l}\text { 1'. Helen knep honom i armen } \\
\text { 'Helen pinched him in the arm' }\end{array}$ & $\begin{array}{l}\text { Alan säger att } \\
\text { 'Alan says that' }\end{array}$ & Målsägare/plaintiff \\
\hline $\begin{array}{l}\text { Direct speech } \\
\text { 2. Alan säger: "Helen knep mig i armen." } \\
\text { "Alan says: "Helen pinched me in the } \\
\text { arm." }\end{array}$ & & Polis/police \\
\hline $\begin{array}{l}\text { 2'. "Helen knep mig i armen." } \\
\text { 'Helen pinched me in the arm.' }\end{array}$ & $\begin{array}{l}\text { Alan säger }+ \\
\text { citatecken } \\
\text { 'Alan says' }+ \\
\text { quotation marks }\end{array}$ & Målsägare/plaintiff \\
\hline \multicolumn{3}{|l|}{ Narration } \\
\hline $\begin{array}{l}\text { 3. Helen knep Alan i armen. } \\
\text { 'Helen pinched Alan in the arm.' }\end{array}$ & - & Målsägare?/plaintiff? \\
\hline
\end{tabular}

Table 1. Overview of the analytical tools for the study: Utterance, framer and source.

In Table 1, we show three main techniques that the police could subsequently use to reproduce Alan's turn in a report. In addition to the commonly established terms direct speech, indirect speech and narration, we use three other terms for the purpose of this analysis: UTTERANCE, SOURCE and FRAMER. By utterance we mean a semantic text unit, typically but not always in the form of a clause like 'Helen pinched Alan's arm'. Sentence fragments like the answer 'No' count as utterances as well since they can be equally meaningful units in the context. Further, an utterance can be embedded in another utterance.

In example (1) in Table 1, 'Alan says that Helen pinched him in the arm' is an utterance, but this utterance contains the embedded utterance 'Helen pinched him in the arm'. We have numbered every utterance in our analysis; embedded utterances share the number of their matrix utterance but are followed by the prime-symbol (').

For each utterance, we have determined who the texts appoint as its SOURCE, and by that we mean the person accountable for an utterance according to the text. For example, the source of the embedded utterance (1'), 'Helen pinched his arm', is Alan. We can see how the pronoun in direct speech changes from mig 'me' to honom 'him' in indirect speech. Alan is the one claiming to have been pinched. The report writer just claims that Alan says he has been pinched. Had this been part of a police report, the police would be the source of this utterance and of all others that cannot be attributed to someone else by the wording of the report. 
Readers of utterance (1) are explicitly shown that Alan is the source of the embedded utterance: 'Helen pinched him in the arm' by the use of a framer.

The source becomes somewhat less clear when narration is used. In example (3), the source is Alan, but this is not stated, only implied - and we have to deduce from the context that it cannot be the police who are the source here, since they were not present at the occasion. The problem of how to judge who is the source of an utterance in the narration will be discussed in the next section.

\section{ANALYSIS AND RESULTS}

In this section, we will show some results and how the analytical model works. To illustrate how the police embed the interviewee's story within their own, we have entered one entire text, utterance by utterance, into a box model with two frames: an outer frame signifying that the police are the source of the utterances and an inner frame with the utterances where the police appoint the interviewee as the source. The box model is shown in Table 2, where the outer and inner frames are marked by bold black lines, and the utterances are numbered and displayed in the order they occur in the text. As above, embedded utterances have the same number as their matrix utterance followed by the prime-symbol $\left({ }^{\prime}\right)$. The inner and outer frames are meant to visualise that our only access to the interviewee's story is through the police's framing. As we will see from the analysis, it can be difficult for a reader to establish who is the source and accountable for a particular utterance in the written interview report, because of a lack of evidential markers.

\subsection{Reported speech and narration marked in various ways}

Presented below is an interview report demonstrating the analytical model which is the main object of this study. The context is that it summarises the third interview, a 15-minute telephone interview, in an assault case involving Maria and Tony, a middle-aged couple living together. They both have substance abuse problems, mainly alcoholic, and are already known to the police because of previous reports of domestic violence. At the time of this interview, Tony is in custody because Maria has reported him to the police for molesting her. During an earlier interview, from 25 January 2007 - referred to in the text below as 'the first interview' - the investigator asked Maria a few questions. The police have already interviewed Tony, and now they are conducting a new interview with Maria, by phone. This text will show that the police use several different ways to report the plaintiff's oral narration in the written report. In the extracts below, we first present the Swedish original text, then the English translation.

Förhör med målsägare (2007-01-25 15:00-15:15, telefonintervju från polishuset) 


\begin{tabular}{|c|c|c|c|c|c|}
\hline & SOURCE: police & & & & \\
\hline 1 & $\begin{array}{l}\text { Informed that Tony has said } \\
\text { that he threw a mobile } \\
\text { telephone at Maria and that it } \\
\text { hit her on the lip, }\end{array}$ & & SOURCE: plaintiff & & FRAMER \\
\hline 2 & Maria says that & & Implicit & Explicit & \\
\hline $2^{\prime}$ & & & & this is not correct & says that \\
\hline 3 & & & $\begin{array}{l}\text { Tony hit her as she said in the first } \\
\text { interview. }\end{array}$ & & \\
\hline 4 & & & He hit her in the face. & & \\
\hline 5 & According to Maria & & & & \\
\hline $5^{\prime}$ & & & & $\begin{array}{l}\text { Tony has been drinking } \\
\text { for a week }\end{array}$ & according to \\
\hline 6 & Maria thinks that & & & & \\
\hline $6^{\prime}$ & & & & he should get help & thinks that \\
\hline 7 & & & & 'This can't go on.' & quot. \\
\hline 8 & & & When Tony is sober he is good & & \\
\hline 9 & & SOURCE: unclear & $\begin{array}{l}\text { When he drinks he becomes 'like crazy' if } \\
\text { Maria 'says the slightest thing wrong' }\end{array}$ & & part. quot. \\
\hline 10 & $\stackrel{?}{\longleftarrow}$ & $\begin{array}{l}\text { Twice before when Maria has } \\
\text { reported him it has led to trial }\end{array}$ & $\stackrel{?}{\longrightarrow}$ & & \\
\hline 11 & & & Tony has been sentenced 'to a month or so'. & & part. quot. \\
\hline 12 & $\stackrel{?}{\longleftarrow}$ & $\begin{array}{l}\text { At one of the trials Maria said } \\
\text { to the judge that there was no } \\
\text { point in sentencing Tony to } \\
\text { prison }\end{array}$ & $\stackrel{?}{\longrightarrow}$ & & \\
\hline 13 & & & He needs care & & \\
\hline 14 & Maria: & & & & \\
\hline $14^{\prime}$ & & & & $\begin{array}{l}\text { "This is how I have had it } \\
\text { for } 14 \text { years.' }\end{array}$ & quot. + Maria: \\
\hline 15 & $\begin{array}{l}\text { When asked about injuries } \\
\text { Maria says that }\end{array}$ & & & & \\
\hline $15^{\prime}$ & & & & $\begin{array}{l}\text { it hurts when she } \\
\text { breathes (ribs) }\end{array}$ & says that \\
\hline 16 & & & & $\begin{array}{l}\text { she has a red mark at her } \\
\text { nose and on her lip and a } \\
\text { big bruise on her wrist }\end{array}$ & \\
\hline 17 & & & $\begin{array}{l}\text { Maria does not remember how many times } \\
\text { she has been forced to call for an 'an 'ballstic'. } \\
\text { ambulance when Tony has gone 'baliste }\end{array}$ & & partial quot. \\
\hline 18 & & & $\begin{array}{l}\text { She has pleaded that Tony should be } \\
\text { allowed to stay on for care, but he has } \\
\text { come home in a taxi }\end{array}$ & & \\
\hline 19 & & & Tony is a periodical drinker. & & \\
\hline 20 & & & $\begin{array}{l}\text { He can be without alcohol for a month or } \\
\text { so, but then he drinks again. }\end{array}$ & & \\
\hline 21 & $\stackrel{?}{\longleftarrow}$ & $\begin{array}{l}\text { Maria has applied for a } \\
\text { restraining order. }\end{array}$ & $\stackrel{?}{\longrightarrow}$ & & \\
\hline 22 & $\begin{array}{l}\text { She is therefore asked how } \\
\text { this is supposed to be } \\
\text { arranged when she and Tony } \\
\text { live at the same address. }\end{array}$ & & & & \\
\hline 23 & Maria: & & & & \\
\hline $23^{\prime}$ & & & & $\begin{array}{l}\text { 'I can't do that to Tony. } \\
\text { He'll have to come home } \\
\text { so that we can talk } \\
\text { through our problems.' }\end{array}$ & quot. + Maria: \\
\hline 24 & $\stackrel{?}{\longleftarrow}$ & $\begin{array}{l}\text { (Maria does not want a } \\
\text { restraining order). }\end{array}$ & $\stackrel{?}{\longrightarrow}$ & & \\
\hline 25 & $\begin{array}{l}\text { Because of interruttions in } \\
\text { telecommunications it has } \\
\text { only been possible th hold a } \\
\text { short interview with Maria. }\end{array}$ & & & & \\
\hline
\end{tabular}

Table 2. How the police frame the plaintiff's words: Sources and framer in the analysed text with Maria and Tony. 
(1) Delgiven att Tony [den misstänkte] har sagt, (1') att han kastade en mobiltelefon mot Maria och att den träffade henne på läppen (2) så säger Maria, (2') att det stämmer inte. (3) Tony slog henne som hon har sagt i första förhöret. (4) Han slog henne i ansiktet.

(5) Enligt Maria (5') så har Tony druckit under en veckas tid. (6) Maria anser (6') att han måste söka hjälp. (7) "Det här går inte." (8) När Tony är nykter så är han snäll. (9) När han dricker så blir han "som tokig” om Maria "säger minsta ord fel."

(10) Två gånger tidigare har Marias anmälningar lett till rättegång. (11) Tony har dömts "till någon månad.” (12) Vid en av rättegångarna så sa Maria till domaren (12') att det inte var någon idé att döma Tony till fängelse. (13) Han behöver vård. (14) Maria: (14') "Så här har jag haft det i 14 år."

(15) Tillfrågad om skador så säger Maria, (15') att hon har ont när hon andas (revbenen), (16) hon har ett rött märke vid näsan och på läppen samt ett stort blåmärke på handleden.

(17) Maria minns inte hur många gånger hon har tvingats att ringa efter ambulans när Tony har fått "tuppjuck.” (18) Hon har vädjat att Tony skall få stanna kvar för vård, men han har kommit hem i taxi.

(19) Tony är periodare. (20) Han kan vara utan alkohol någon månad, men sedan dricker han igen.

(21) Maria har ansökt om besöksförbud. (22) Hon får därför frågan hur detta skall ordnas då hon och Tony bor på samma adress. (23) Maria: (23') "Jag kan inte göra så mot Tony. Han får komma hem så att vi kan prata igenom våra problem.” (24) (Maria önskar inget besöksförbud).

(25) På grund av avbrott i telekommunikationerna har det endast gått att hålla ett kort förhör med Maria.

'Interview with the plaintiff Maria (25 Jan 2007, 15:00-15:15, phone interview from the police station)

'(1) Informed that Tony [the suspect] has said that he threw a mobile telephone at Maria and that it hit her on the lip, (2) Maria says (2') that this is not correct. (3) Tony hit her as she said in the first interview. (4) He hit her in the face.

'(5) According to Maria, (5') Tony has been drinking for a week. (6) Maria thinks (6') that he should get help. (7) "This can't go on." (8) When Tony is sober he is good. (9) When he drinks he becomes "like crazy" if Maria "says the slightest thing wrong". 
'(10) Twice before when Maria has reported him it has led to trial. (11) Tony has been sentenced "to a month or so". (12) At one of the trials Maria said to the judge that there was no point in sentencing Tony to prison. (13) He needs care. (14) Maria: (14') "This is how I have had it for 14 years."

'(15) When asked about injuries Maria says (15') that it hurts when she breathes (ribs), (16) she has a red mark at her nose and on her lip and a big bruise on her wrist.

'(17) Maria does not remember how many times she has been forced to call for an ambulance when Tony has gone "ballistic". (18) She has pleaded that Tony should be allowed to stay on for care, but he has come home in a taxi.

'(19) Tony is a periodical drinker. (20) He can be without alcohol for a month or so, but then he drinks again.

'(21) Maria has applied for a restraining order. (22) She is therefore asked how this is supposed to be arranged when she and Tony live at the same address. (23) Maria: (23') "I can't do that to Tony. He'll have to come home so that we can talk through our problems." (24) (Maria does not want a restraining order).

'(25) Because of interruptions in telecommunications it has only been possible to hold a short interview with Maria.'

In this report of the telephone interview with Maria, there are three main ways to use quotation marks (which are "double" in the original Swedish but 'single' in the translation and analysis of the text, by convention in British English and the present journal): around direct speech with an explicit source (e.g. Maria: 'This is how I have had it for 14 years', example (14)); around direct speech without a framer or source (e.g. 'This can't go on', example (7)); and around part of utterance (e.g. 'like crazy', example (9)). There does not seem to be a clear and consistent strategy for how quotes are used in Swedish police written records. As previous research has shown (Jönsson 1988, Gumbel 2000, Pappinen 2010), when quotation marks are used around a part of an utterance in Swedish police texts, they often function as scare quotes, marking distance from words that are not normally used in a legal context, such as slang or vulgar words, even though the writing guidelines explicitly advise against this. There is an example of this in the interview with Maria, where quotation marks are used around 'ballistic' in utterance (17): ( . . . to call for an ambulance when Tony has gone 'ballistic'). The word 'ballistic' is likely Maria's word, therefore the quotation marks are used for verbatim quoting, but since the investigator has not put the whole utterance in quotation marks, it indicates that the quotation marks also function as a distancing device, i.e. as scare quotes. According to the police recommendations in Riktlinjer för skrivande inom polisen (2006), investigators are only supposed to use quotation marks for verbatim utterances and not scare quotes and verbatim quoting 
at the same time. The use of quotation marks here leaves it up to the reader to interpret whether the word should be taken as a verbatim quote or something that the investigator wants to mark a distance to, and may then apply to both form and content.

In Table 2, the inner frame is divided into two columns, to distinguish between utterances for which the plaintiff is explicitly construed as the source by the use of a framer and utterances for which she is only implicitly the source. For example, the source of utterance ( $\left.2^{\prime}\right)$ ('this is not correct') is the plaintiff, and this is marked explicitly with the framer 'Maria says that'. But in the two following utterances, (3) and (4), the reader has to infer that it is still the voice of Maria we are hearing. 'He hit her in the face' (utterance (4)) is reported to the reader as a fact but given the context, Maria is the only plausible source. But not all utterances without a framer have Maria as the implicit source. For example, it cannot be disputed that utterance (25), about the interview being ended because of a bad phone connection, must have the police as its source.

The quotation marks around utterance (7) ('This can't go on') indicates that it is a verbatim quotation of Maria, even though there is no explicit framer (see Table 2). Thus it is a less clear way of signalling direct speech, since sometimes the same technique is used to mark second-degree embeddings when the interviewee in the oral narrative is reporting someone else's speech (see Section 6.2).

It is often hard to see what the exact purpose of a certain quotation in the analysed text is and why some (parts of) utterances have quotation marks and others have not. In utterances (12)-(14), for example, the police have chosen to use quotes around 'This is how I've had it for 14 years', but we find it hard to tell why the police have not put utterance (13) ('he needs care') in quotation marks, since it is likely a verbatim quotation from Maria.

It is hard to draw the line between instances where the source is unclear and where it is implicitly the plaintiff, as an utterance in the form of narration may fit into either of the two. An important contextual factor to keep in mind, however, is that the institutional purpose of the interview report is to capture the interviewee's story. Therefore the default source of everything written is supposed to be the interviewee, if nothing else speaks against this interpretation. But it is not as simple as this, since there are utterances in the form of narration that must have the police as their source, as evidenced by the phone line utterance ((25) in Table 2). Our main criterion of demarcation has been if the utterance contains information about the case that the police might have access to by other means than collecting it from the interviewee's story. In that case it has been placed in the column 'SOURCE: unclear'. If on the other hand it seems most likely to be words coming from the interviewee, e.g. because the utterance contains subjective judgements or quotations, we have categorised it as having the plaintiff as the 'Implicit (source)'.

Utterances (15) and (16) are relevant for establishing whether a crime has been committed or not, because they concern injuries - an important constituent element 
of the reported offence, molesting. The framer 'Maria says that' (in (15)) makes her the explicit source of utterance $\left(15^{\prime}\right)$, 'it hurts when she breathes'. But this utterance is followed by a simple declarative utterance, 'she has a red mark at her nose and on her lip and a big bruise on her wrist', which could give the reader the impression that these wounds were observed by the police. However, this is a telephone interview and the description of the bruises can only be ascribed to Maria, since the police officer cannot see her wounds. One could of course argue that utterance (16) about Maria's wounds should be considered as a subordinate clause and a continuation of $\left(15^{\prime}\right)$, but since comma splices are common in police writing, 'Maria says' might only be intended to frame the utterance about her perceived rib pain. This ambiguity of the analysis indicates that the placing of framers is essential for interpretation.

While it is true that an interview conducted over the phone gives no access to observe the plaintiff's wounds, we would argue that the reader should not have to pay careful attention to the medium of the interview in order to correctly capture the source of different utterances. This is particularly important when it comes to wounds, since of course wounds that have been documented by the police constitute firmer evidence than wounds that were never documented.

Especially hard to categorise are utterances (19)-(20), retelling Tony's need for care, since he is a periodical drinker. There are arguments both for and against attributing them to the plaintiff. This uncertainty may be considered a weak point in our analysis, but at the same time underlines one of our main points: no linguistic material carries an entirely fixed and stable meaning; instead every element is more or less open to different reader interpretations. It also shows that in a text voices are blended in a way that may make them hard to separate, and once more reinforces the fact that the meaning potentials of face-to-face dialogues differ from the meaning potentials of written interview reports.

The examples discussed so far lead to the question: If some of the non-embedded utterances have Maria as a source and some have the police, how can the reader be sure when it is one or the other? In this interview report there are several examples where it is hard to be completely sure who is the source of an utterance. These utterances are marked in the column shaded in grey in Table 2, for example utterance (10), 'Twice before when Maria has reported him it has led to trial', and utterance (21), 'Maria has applied for a restraining order'. We cannot be sure whether the restraining order forms part of previous knowledge gathered from the original complaint or something she states during the interview. In the next utterance, the police officer asks her how restraining Tony could be arranged when she and he live at the same address, which constitutes an initiative by the police to challenge the logic of this complaint. Utterance (23) is a quotation explicitly attributed to Maria, representing her reply to this question as direct speech ('I cannot do that to Tony. ...'). The outcome of this interaction seems to be the police officer's conclusion about Maria's wishes: utterance (24) in parentheses: ('Maria does not want a restraining order'). 


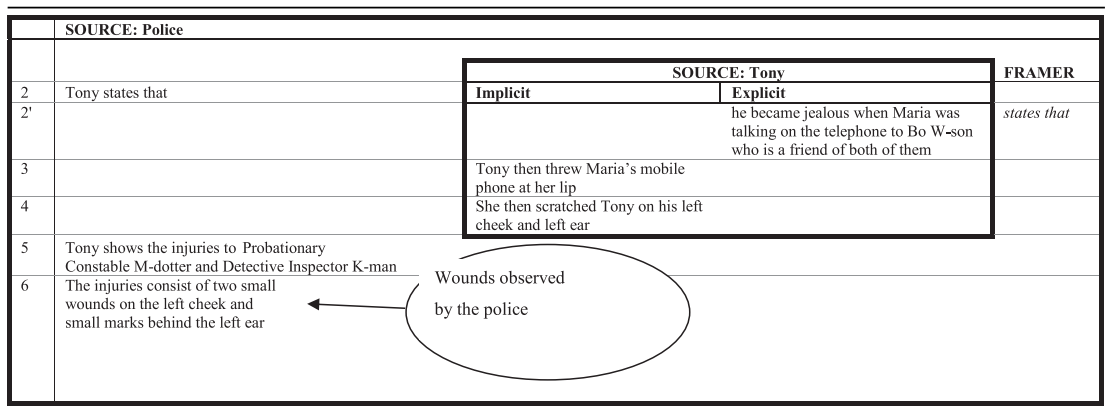

Table 3. Extracts showing how utterances concerning wounds are framed in the interviews with Tony.

\subsection{Quotation marks for constituent elements and embeddings}

In this section we will demonstrate how quotation marks are used when the investigator retells actions of the suspect that could be considered as constituent elements of the offence. We will use the same case of domestic violence as above. In Table 3, we have extracted parts of the report. The first extract is from the interview with Tony concerning the wounds he received in his fight with Maria, which is compared to an extract from Maria's interview, where she reports her wounds from the fight.

(2) Han uppger (2') att han blev svartsjuk när Maria pratade $i$ telefon med Bo W-son som är en gemensam kompis till dem. (3) Tony kastade då Marias mobiltelefon på hennes läpp. (4) Därefter rev hon Tony på hans vänstra kind och vänster öra. (5) Tony visar skadorna för polisassistent M-dotter och kriminalinspektör K-man. (6) Skadorna består av två mindre sår på vänster kind och mindre märken bakom vänster öra.

'(2) He states (2') that he became jealous when Maria was talking on the telephone to Bo W-son who is a friend of theirs. (3) Tony then threw Maria's mobile phone at her lip. (4) She then scratched Tony on his left cheek and left ear. (5) Tony shows the injuries to Probationary Constable M-daughter and Detective Inspector K-man. (6) The injuries consist of two small wounds on the left cheek and small marks behind the left ear.'

In Table 3 we can see an extract from Tony's interview report. The table makes it clear that Tony's wounds are observed by the police through the utterance 'Tony shows the injuries to Probationary Constable M-dotter and Detective Inspector K-man. The injuries consist of two small wounds on the left cheek and small marks behind the left ear'. 


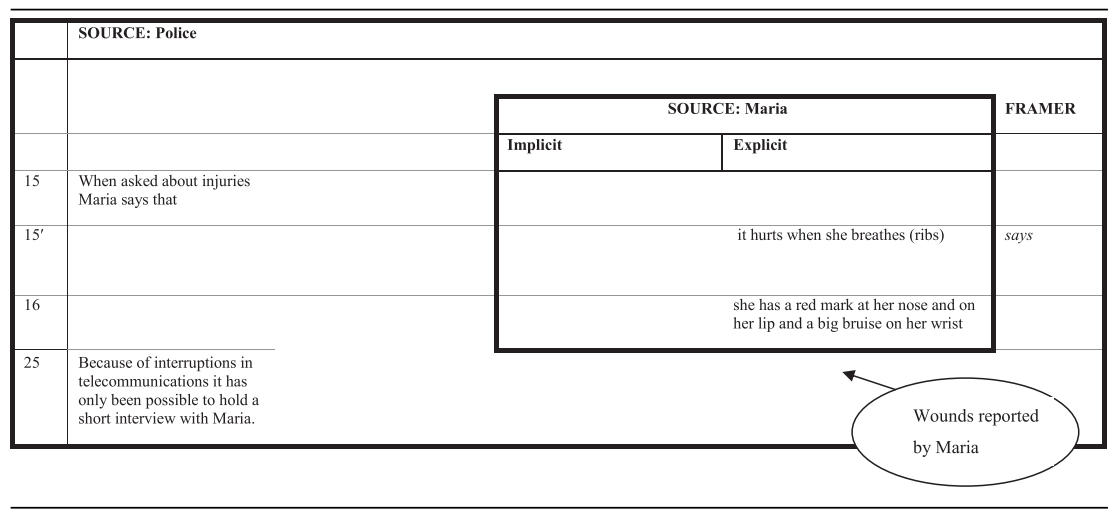

Table 4. Extracts showing how utterances concerning wounds are framed in the interviews with Maria.

In Table 4 Maria's interview it is less clear, as we have argued above, but the wounds are most likely reported by Maria, not observed by the investigator, since it is a telephone interview.

In the next extract, we will show some second-degree embeddings in quotation marks. The example used is an extract from an interview report taken from another case in the corpus, concerning domestic violence in the home of Daisy and Peter, who are married. The suspect is a compulsive alcoholic, who molests and threatens his wife when he is drunk.

Förhör med målsägare Daisy

(1) Sedan den 15 november 2007 så har Daisy haft problem med Peter. (2) Nästan varje alternativt varannan dag så har Peter hotat och misshandlat henne. (3) Enligt Daisy (3') så är Peter alltid berusad när han gör det. (4) Peter brukar kalla henne för (4') "skitfitta" när han misshandlar henne. (5) Detta brukar han göra genom att slå henne med knytnävslag mot ansiktet. (6) Daisy har inte uppsökt någon läkarvård för skadorna som har uppkommit sedan den 15 november 2007, (7) men hon har fått väldigt ont av slagen samt (8) så har hon fått näsblod. (9) Peter brukar även säga; (9') "Ska du ringa polisen igen?", (9') "Ska du få mig inlåst igen?”, (9') "Du skulle bara våga anmäla mig en gång till!", (9') "Jag ska döda dig om du anmäler mig igen, och (9') det så är det sista jag ska göra”. 10 Detta säger Peter $i$ samband med att han misshandlar Daisy.

'Interview with plaintiff Daisy

'(1) Since 15 May 2007 Daisy has had problems with Peter. (2) Almost every day or every other day Peter has threatened and beaten her. (3) According to Daisy, (3') Peter is always drunk when he does this. (4) Peter usually calls her (4') "filthy cunt" when he abuses her. (5) What he usually does is punch her in 
the face. (6) Daisy has not sought any medical treatment for injuries incurred since 15 May 2007, (7) but she has had a lot of pain from the blows, and (8) she has had nosebleeds. (9) Peter also usually says, (9') "Are you going to call the police again?", $\left(9^{\prime}\right)$ "Will you get me locked up again?", $\left(9^{\prime}\right)$ "You would not dare report me again!", $\left(9^{\prime}\right)$ "I'll kill you if you report me again, $\left(9^{\prime}\right)$ if it's the last thing I do." (10) Peter says this when he is assaulting Daisy.'

The investigator's writing technique in this text is to use both a framer, (9) (Peter usually says), and put what he says in quotation marks to enclose Daisy's words about Peter's utterances, for example, $\left(9^{\prime}\right)$ 'Are you going to call the police again?', $\left(9^{\prime}\right)$ 'You would not dare report me again!', (9') 'I'll kill you if you report me again, if it's the last thing I do'. These quotations are all second-degree embeddings quoting Daisy, who is in turn quoting Peter at the scene of the crime. Explicit framers make Peter the source of all the quotations in this text. While this use of quotation marks may signal a verbatim rendering, it is not of the original utterances (by Peter) but of how Daisy reports them. Since she is the plaintiff in this case, she is likely to be a highly biased interviewee, affecting the evidential value of the reported utterances.

The parts cited in quotation marks are important for the investigation, since they are constituent elements of the offence, and if they are considered threats, for instance, Peter can be prosecuted for them as well as for the physical abuse. There are no speech reporting markers pointing to Daisy as the source of the story in which the quotations are embedded. Instead, her story is retold in the report in the form of narration with Peter's utterances embedded in quotation marks in the story.

We will now turn to yet another case, where second-degree and third-degree embeddings are handled in different ways in the same text. The following example is an interview with Ali. He is in custody because Aisha has reported him to the police for molesting her, and he is suspected of assaulting both Aisha and Aisha's daughter, Zara, who is Ali's stepdaughter. The couple do not live together and the interview is carried out with an interpreter, as Ali does not speak Swedish. Ali lives in the USA, but was visiting his family in Sweden when the assault happened.

\section{Förhör med misstänkt Ali}

(1) Nästa morgon steg Ali upp. (2) Han frågade Aisha (2') vad som var problemet varför hon var arg. (3) Aisha svarade inte utan hon bara stirrade på Ali. (4) Ali frågade då (4') "varför har du en sådan bitchi attityd?", (4") enligt tolken betyder det stötande attityd. (5) Sedan gick Ali tillbaka till köket. (6) Han tände en cigarrett och drack kaffe. (7) Aisha kom tillbaka till köket och frågade (7') varför Ali kallade henne för en bitch, (7") enligt tolken översatt till hora. (8) Ali sade då (8') att jag kallade inte dig för bitch, jag sade att du hade en bitchi attityd, (9) enligt tolken betyder det att (9') Ali sade (9") "jag kallade inte dig för hora, jag sa att du hade en stötande attityd”. 
'Interview with suspect Ali

'(1) The next morning he got up. (2) He asked Aisha (2') what the problem was, why she was angry. (3) Aisha did not answer but just stared at Ali. (4) Ali then asked, (4') "Why do you have such a bitchy attitude?" (4") According to the interpreter, this means an offensive attitude. (5) Then Ali returned to the kitchen.

(6) He lit a cigarette and drank coffee. (7) Aisha came back to the kitchen and asked ( $\left.7^{\prime}\right)$ why Ali called her a bitch, ( $\left.7^{\prime \prime}\right)$ translated by the interpreter as whore.

(8) Ali then said ( $8^{\prime}$ ) I did not call you bitch, I said you had a bitchy attitude. (9) According to the interpreter it means that (9') Ali said (9") "I did not call you a whore, I said you had an offensive attitude.",

For the investigator, this is a complex interview situation using an interpreter during the interview. Since we are already at the first level of embedding at the start of the excerpt, it is difficult to visualise second- and third-degree embeddings (but see Table 5, of utterance (7)).

[The investigator

writes that]

( $\left.7^{\prime \prime}\right)$ the

interpreter

says that

[Ali says that]

(7) Aisha said 'why did you call me a bitch'

Table 5. Extracts showing a paraphrase of utterance (7) with second- and third-degree embedded utterances in the interviews with Ali. Square brackets indicate sources not explicitly mentioned but clearly inferable from the context.

To illustrate the use of quotation marks in embeddings we will comment on some of the utterances in the interview with the suspect, Ali. Number (4'), 'Why do you have such a bitchy attitude?', is a second-degree embedding, since Ali is quoting himself in the interview. If we compare example (4') with ( $\left.8^{\prime}\right)$ (I did not call you bitch ...), we see that there are quotations marks around (4'), 'Why do you have such a bitchy attitude?', but not around ( $\left.8^{\prime}\right)$. This is also a second-degree embedding, which further contains a third-degree embedding, since Ali is quoting himself within his quotation $\left(8^{\prime}\right)$... 'I said you had a bitchy attitude'. This shows that quotation markers are used rather randomly.

Utterances (7), (7') and (7') also display several embeddings representing different sources. To get a full overview of the sources, it is necessary to paraphrase these utterances somewhat, as in Table 5. As illustrated in Table 5, the embeddings and source attribution are very complex, and can be paraphrased as follows: The 
investigator writes that the interpreter says that Ali says that Aisha said 'why did you call me a bitch'.

The last utterance $\left(\left(9^{\prime}\right)\right.$, 'I did not call you a whore, I said you had an offensive attitude') can be perceived as a third-degree embedding since it is the interpreter's words.

The fact that there is an interpreter present who interprets to and from Swedish complicates the understanding and interpretation of what appears in the interview, since there is a third party who ideally ventriloquises the suspect. Neither the police interviewer nor the reader can properly establish the evidential source of the utterances or how they were originally formulated because most of the time it is in a language that the investigator does not understand. It is not clear from the written interview what the suspect's native language is, but it is an African language, probably Somali. The suspect lives in the USA and speaks English; some of the conversation in the interview seems to be in English, since there are English phrases intermixed in the Swedish text, and some in the suspect's native language (after interpretation to Swedish).

All the examples show that transforming the verbal representation of events into a written police report is a complex process, where the investigator has to manage the task of the oral interaction as well as writing the text.

\section{CONCLUSION AND DISCUSSION}

In this section we discuss our findings in terms of our theoretical and methodological framework. We address the question of what techniques the police use to retell the interviewees' story and the question of reportative evidentiality, i.e. who is the source and seems accountable for the utterances in the text, which is always relevant and sometimes crucial in a legal context. As evidenced above, the police use a mix of indirect and direct reported speech - with or without a framer or quotation marks and narration, to represent the interviewees' story, without any obvious, consistent strategy. The analysis and the proposed analytical model also show that the texts do not have any consistency in documenting utterances from different sources. The police officers do not consistently show whether utterances are embedded or not by using framers or quotation marks. Finally, the analysis demonstrates that it is a complex and sometimes uncertain process to try to uncover the structure of the original narrative from a written legal report.

All in all, the documents do not express reportative evidentiality in a transparent manner. We can see no obvious reason, except possibly for a wish for variation in mode of presentation, why some of the utterances which have the interviewee as a source have a framer and some do not. The text would of course be all too rigid if the investigators began every sentence with a framer such as 'Maria said' or 'Tony said'. But the problem with reportative evidentiality persists, and the investigators 
have to solve it in an appropriate, clear and understandable way for the genre and the reader. The obvious answer to who is accountable for the utterance would be the interviewee but, as we have shown, this is not always the case. Sometimes the police are the source of the utterance and sometimes it is hard to be completely sure who the source is. The latter only happens with utterances where no framer is used. These techniques create unclear evidential traces in the text. The results indicate that there are deficiencies in the means of written language to indicate sources in speech, when it comes to retelling face-to-face communication. It seems as if it cannot be fully reproduced in written text, especially when the interviews are recontextualised, taken from their original context and put in another. The use of quotation marks also varies. We distinguish three ways of using quotation marks: around a direct speech utterance in connection with a framer, around a direct speech utterance without a framer and around part of an utterance. The quotation marks seem to be used for both verbatim utterances and to mark a distance from the colloquial style of the interviewee. In other words, quotation marks are used not only as a tool to mark verbatim utterances that are constituent elements of a suspected crime, such as threats and verbal abuse ('filthy cunt' in the case with Daisy and Peter), but also as a stylistic tool, dramatising the interview, creating a stronger personal presence of the interviewee and giving the reader a flavour of the interviewee's personal way of speaking (see Galatolo 2007:213-214). One trivial explanation could be that it is easier and more time-saving to quote, as the writer then does not have to consider how the interviewee's words should be reformulated. Another explanation could be that putting the interviewee's slang expressions in scare quotes can be seen as a measure by which the police try to retain their authoritative voice and keep it clean and untouched by the more vulgar lifeworld of the interviewee (see Matoesian 2000:911-912). Such a wish could explain why Swedish police continue to use quotation marks in this fashion, even though their own writing guidelines explicitly advise against other uses than verbatim quotation:

'Reserve quotes for verbatim expressions. Do not use them to mark your personal discretion, for example, from a particular word form. Instead, try to find a word that is to be considered correct in a formal text. The reader may not know in which cases you actually quote an interviewee or if you use quotation marks to mark your own words as colloquial language.' (translated from Swedish passage in Riktlinjer för skrivande inom polisen 2006:12-13)

One problem which ought to be discussed is the institutional and professional views on how language expresses meaning and evidentiality, how these texts should be written and how potential polyvocality should be represented in the best possible way in the texts. As noted above, it is a complex cognitive process to write an interview report (Rock 2001:42). As professionals of the legal system, police 
officers are expected to be neutral vehicles, objectively putting the spoken words of the interviewee into writing. This is an impossible ideal but useful compromises between ideals and practice can be reached. A dialogical perspective on meaning and understanding proceeds from the premise that tensions and struggles are always present. Human action and communication are always oriented towards agreement, but at the same time, meanings and understandings can never be made totally explicit, since one person's understanding, views and experience of the world will never be entirely identical to another's. This tension is something that legal professionals are aware of, since it is the basis for their everyday work. Legal professionals do not view a verdict as an absolute truth of guilt or innocence, but rather as an attempt to resolve, as fairly as possible, tensions and conflicting perspectives that they know will always be present in human society.

How can the problem of potentially unclear reportative evidentiality be solved? We definitely do not want to suggest that every sentence retelling the interviewee's words should begin with a framer; that would give highly repetitive texts that would not be reader-friendly. But the police writing the reports ought to pay careful attention to the placing and potential scope of framers (see utterances (10), (12) and (21) in Maria and Tony's case above), so that no utterance is left unnecessarily open to interpretation.

If the investigators focused on, and actively discussed, the dialogical tensions always present in language use, it might bring them closer to their goal of creating texts with high evidential value that also appear coherent. It would also make the genre of investigation report develop and possibly be more functional in its context, and it would be ideal if training for the police students also included the reading and discussion of texts and their potential meanings. Police academies and in-service training could provide practice in writing, aimed at teaching how to handle different kinds of evidential issues and deixis in narration in direct and indirect reported speech, with regard to accountability and how to use framers to establish the source and thereby evidential value of the reports. This could stimulate awareness of writing and reflection on how investigative reports may be interpreted.

\section{ACKNOWLEDGEMENTS}

We would like to thank our anonymous reviewers and the special issue editors, who contributed constructive solutions and suggestions for creative changes.

\section{NOTES}

1. It could also be explained in a model of enunciation (see Chafe 1986, Gerard 1992) with an original event (or events) with two participants: plaintiff and suspect, where the plaintiff 
(re)tells the event(s) and the investigator reports in writing on the interview with the plaintiff, and the suspect's (re)telling of event(s) and the reports (in writing) on the interview with the suspect. However, we will try out our tentative model in this study (see Section 5).

2. A general difference between the Swedish interview report and the English witness statement, as described by Rock, is that the Swedish report retells the words of the interviewee in the third person, often using speech reporting markers, for example 'When asked about injuries Maria says that it hurts when she breathes', while the witness statement is written from the interviewee's point of view with first person pronouns and no trace of the police question that preceded the statement 'It hurts when I breathe'. The Dutch procèsverbal can be said to occupy an intermediate position, since it marks police questions but is written with first person pronouns from the interviewee's perspective (Komter 2006, van Charldorp 2011).

\section{REFERENCES}

Aikhenvald, Alexandra Y. 2007. Information source and evidentiality: What can we conclude. Italian Journal of Linguistics / Rivista di Linguistica 19(1), 209-227.

Ajagán-Lester, Luis, Per Ledin \& Henrik Rahm. 2003. Intertextualiteter. In Boel Englund \& Per Ledin (eds.), Teoretiska perspektiv på sakprosa, 203-238. Lund: Studentlitteratur.

Andrus, Jennifer. 2015. Entextualizing Domestic Violence: Language Ideology and Violence against Women in the Anglo-American Hearsay Principle. New York: Oxford University Press.

Ask, Sofia. 2018. 'She had it coming?': An experimental study of text interpretation in a police classroom setting. Nordic Journal of Linguistics 41(2), 133-153.

Bakhtin, Mikhail. 1981. Discourse in the novel. In The Dialogic Imagination: Four Essays, edited by Michael Holquist. Austin, TX: University of Texas.

Bakhtin, Mikhail. 1986. Speech Genres and Other Late Essays, vol. 8. Austin, TX: University of Texas Press.

Bauman, Richard \& Charles L. Briggs. 1990. Poetics and performance as critical perspectives on language and social life. Annual Review of Anthropology 19, 59-88.

Boye, Kasper. 2010. Semantic maps and the identification of cross-linguistic generic categories: Evidentiality and its relation to epistemic modality. Linguistic Discovery $8(1), 4-22$.

Boye, Kasper \& Peter Harder. 2009. Evidentiality: Linguistic categories and grammaticalization. Functions of Language 16(1), 9-43.

Byrman, Gunilla. 2014. Police writing techniques in reported interviews. In Melchor C. de Guzman, Aiedeo Mintie Das \& Dilip K. Das (eds.), The Evolution of Policing: Worldwide Innovations and Insights, 247-262. New York: Taylor \& Francis.

Byrman, Gunilla \& Ylva Byrman. 2012. Narrative techniques in written police records in Sweden. Presented at the IAFL conference in Kuala Lumpur, 7 July 2012.

Byrman, Ylva. 2017. Så fångas de misstänktas ord: Förhör och dokumentationspraktiker på Skattebrottsenheten [Capturing the suspect's words: Investigative interviewing and documentation practices at the Swedish tax fraud unit]. Ph.D. thesis, Göteborg: Göteborgs universitet.

Chafe, Wallace. 1986. Evidentiality in English conversation and academic writing. In Wallace Chafe \& Johanna Nichols (eds.), Evidentiality: The Linguistic Coding of Epistemology, 261-272. Norwood, NJ: Ablex. 
Chouliaraki, Lilie \& Norman Fairclough. 1999. Discourse in Late Modernity: Rethinking Critical Discourse Analysis. Edinburgh: Edinburgh University Press.

Codex. 1990. Forskningsetiska principer inom humanistisk-samhällsvetenskaplig forskning [Principles for research ethics in the humanities and social sciences]. http://www.codex.vr.se/texts/HSFR.pdf (accessed 9 January 2012). The Research Council for Humanities-Social Research in Sweden.

Fairclough, Norman. 1992. Discourse and Social Change. Cambridge: Polity.

Fairclough, Norman. 1995. Critical Discourse Analysis: The Critical Study of Language. London: Longman.

Fludernik, Monika. 1993. The Fictions of Language and the Languages of Fiction: The Linguistic Representation of Speech and Consciousness. London: Routledge.

Förundersökningskungörelsen [Investigation Report Decree]. 1947. https://lagen.nu/1947:948 (accessed 9 January 2012).

Galatolo, Renata. 2007. Active voice in court. In Elizabeth Holt \& Rebecca Clift (eds.), Reporting Talk: Reported Speech in Interaction, 195-220. Cambridge: Cambridge University Press.

Garfinkel, Harold. 1967. Studies in Ethnomethodology. Englewood Cliffs, NJ: Prentice-Hall.

Genette, Gérard. 1992. The Architext: An Introduction. Berkeley, CA: University of California Press.

Gumbel, Ingatora. 2000. Hörd angående misshandel: Polisens protokoll vid förhör med misshandlade kvinnor och misstänkta män [Interviewed concerning assault: Police investigative interviews with abused women and male suspects]. Stockholm: Stockholm University, Department of Scandinavian Languages.

Haworth, Kate. 2013. Audience design in the police interview: The interactional and judicial consequences of audience orientation. Language in Society 42(1), 45-69.

Heffer, Chris. 2005. The Language of Jury Trial: A Corpus-aided Analysis of Legal-Lay Discourse. New York: Palgrave Macmillan.

Heffer, Chris. 2010. Narrative in the trial: Constructing crime stories in the court. In Malcolm Coulthard \& Alison Johnson (eds.), Routledge Handbook of Forensic Linguistics, 199-217. New York: Routledge.

Heffer, Chris, Frances Rock \& John M. Conley (eds.). 2013. Legal-Lay Communication: Textual Travels in the Law. New York: Oxford University Press.

Heydon, Georgina. 2013. From legislation to the courts. In Heffer et al. (eds.), 55-77.

Holt, Elizabeth \& Alison Johnson. 2010. Legal talk. Socio-pragmatic aspects of legal talk: Police interviews and trial discourse. In Coulthard \& Johnson (eds.), 21-36.

Jakobs, Eva-Maria. 2008. Berufliches Schreiben: Ausbildung, Training, Coaching. In Eva-Maria Jakobs \& Katrin Lehnen (eds.), Coaching und berufliches Schreiben, 1-14. Frankfurt/M.: Peter Lang.

Johnson, Alison. 2013. Embedding police interviews in the prosecution in the Shipman trial. In Heffer et al. (eds.), 147-167.

Jönsson, Linda. 1988. Polisförhöret som kommunikationssituation [Police interrogations as a communication situation]. Ph.D. thesis, Linköping University.

Komter, Martha. 2006. From talk to text: The interactional construction of a police record. Research on Language and Social Interaction 39(3), 201-228.

Komter, Martha. 2013. Travels of a suspect's statement. In Heffer et al. (eds.), 126-146.

Leech, Geoffrey \& Mick Short. 2007. Style in Fiction: A Linguistic Introduction to English Fictional Prose, 2nd edn. Harlow: Longman. 
Linell, Per. 2009. Rethinking Language, Mind, and World Dialogically: Interactional and Contextual Theories of Human Sense-making. Charlotte, NC: Information Age.

Matoesian, Gregory M. 2000. Intertextual authority in reported speech: Production media in the Kennedy Smith rape trial. Journal of Pragmatics 32(7), 879-914.

Mushin, Ilana. 2001. Evidentiality and Epistemological Stance: Narrative Retelling. Amsterdam: John Benjamins.

Pappinen, Anna. 2010. Återberättade berättelser: Om anföringsbruk i förhörstext [Retold stories: Reported speech in written police interrogations]. BA thesis, Department of Language and Literature, Linnaeus University. http://lnu.diva-portal.org/smash/ record.jsf?searchId=1\&pid=diva2:325129 (accessed 9 January 2012).

Park, Joseph Sung-Yul \& Mary Bucholtz. 2009. Introduction. Public transcripts: Entextualization and linguistic representation in institutional contexts. In Joseph Sung-Yul Park \& Mary Bucholtz (eds.), special issue of Text \& Talk 29(5), 485-502.

Riktlinjer för skrivande inom polisen [Guidelines for writing in the police]. 2006. 4th edn. Stockholm: Rikspolisstyrelsen.

Rock, Frances. 2001. The genesis of a witness statement. International Journal of Speech Language and the Law 8(2), 44-72.

Rock, Frances. 2010. Witnesses and suspects in interviews: Collecting oral evidence. The police, the public and the written words. In Coulthard \& Johnson (eds.), 126-138.

Seawright, Leslie. 2012. The Literacy Practices of Law Enforcement. Ph.D. dissertation, University of Arkansas.

Spinuzzi, Clay \& Eva-Maria Jakobs. 2013. Integrated writers, integrated writing, and the integration of distributed work. Connexions: International Professional Communication Journal 1(1), 119-124.

Toolan, Michael J. 2001. Narrative: A Critical Linguistic Introduction, 2nd edn. London: Routledge.

van Charldorp, Tessa. 2011. From Police Interrogation to Police Record. Amsterdam: Uitgeverij BOXPress, Oisterwijk.

Vološinov, Valentin Nikolaevic. 1983. The construction of the utterance. In Ann Shukman (ed.), Bakhtin School Papers, 114-138. Oxford: RPT Publications.

Vygotskij, Lev Semenovič. 1978. Mind and Society: The Development of Higher Psychological Processes. Cambridge, MA \& London: Harvard University Press.

Yang, Linxiu. 2014. Evidentiality in English research articles of applied linguistics: From the perspective of meta discourse. Journal of Language Teaching and Research 5(3), 581-591. 